\title{
Christmas of a Pioneer Family
}

\author{
By Matte L. BaIlY ${ }^{1}$ \\ Historian Pocahontas County Historical Society
}

Ludwick D. and Eliza Turner had experienced but few seasons in Northwest Iowa since their arrival in the prairie schooner. They had traveled from New York state; first by rail, later by stage and ferry, and last by ox team.

Another miraculous prairie summer had passed. The once gently rolling Iowa uplands on which grew the many colored beautiful prairie flowers, were bleak and cold looking. The long grasses and canes, high as a man on horseback, were brown, bent and broken. Ludwick had watched the muskrat houses fast appearing in the sloughs, and was planning a busy winter, hoping thereby to make a few dollars. Eliza was in need of a new calico dress to wear on certain occasions. She had been very busy picking and preparing wild strawberries, plums, grapes and wild crab apples from nearby hillsides and timber spots, looking ahead to Christmas time. Also, she had learned the art of making delicious foods from the meager supplies of pioneer times, and had become quite proficient in making dainty scraps of lace, silk and woolen into little garments, cushions and toy dolls: She had salvaged the material from garments she had worn while a teacher in the public schools of New York state.

Ludwick had returned from trapping very tired. He had skinned the muskrats and stretched the furs to dry. He had retired early on the homemade bedstead, with the stuffed hay bed tick resting on cords of rope drawn through the bedstead. Eliza had not completed her tasks; she lighted two candles, placing one in the window, as a guide to any traveler, and as an invitation, "Here you are welcome." By" the other candle on a table in the "soddie" she finished off

${ }^{1}$ Matie L.. Turner Baily is the only living descendant of Ludwig D. and Eliza Turner. 
a pair of wristlets for Ludwick from ravelings of a blue wool hood of her girthood days.

As she knitted on, she thought of the beauties of the prairie she had learned to admire and truly love. That very evening she had witnessed one of those many sunsets that never were described-a prairie sunset. There were sundogs above and below the sun. Beautiful golden rays and streamers adorned the western sky. There was a distance of a score of miles across the flat prairie before the eye met the horizon, and the snow glistened like millions of diamonds all the way to the west.

Then suddenly her thoughts were turned to those other Christmas times in New York state when father and mother lived in a commodious, well-built house where timber was plentiful. She visioned them in their armchairs, close to the huge fireplace, in which the great logs crackled and burned while the young folks roasted apples and chestnuts and planned sleighing parties. And, oh! the pretty Christmas trees-then like the true pioneer mother, she mused"Ludwick and I came to the West to build a home."

She said a prayer for all and went to her bed to dream of the time when the "soddie" would be replaced by a frame house. Many herds of cattle and horses would feed upon these grassy plains. Neighbors would be close, churches and schools built and this beautiful Iowa prairie land would "blossom as a rose." And because there was so everlastingly much of it, it might help feed some of the East, if railroads ever came.

And she lived to see the change of sixty odd years. Our beloved Iowa is where it is today because of. sacrafices and courage of pioneers. And last, but not least, they lived by Bible faith and honest toil, not counting hours but rather service. 
Copyright of Annals of Iowa is the property of State of Iowa, by \& through the State Historical Society of Iowa and its content may not be copied or emailed to multiple sites or posted to a listserv without the copyright holder's express written permission. However, users may print, download, or email articles for individual use. 